\title{
Marine Biodiversity in the Caribbean UK Overseas Territories: Perceived Threats and Constraints to Environmental Management
}

\author{
La Biodiversidad Marina en los Territorios del Caribe del Reino Unido: \\ Las Amenazas y las Limitaciones a la Gestión Ambiental
}

\section{La Biodiversité Marine dans les Britanniques des Caraïbes Territoires d'outre-mer : Menaces et Contraintes Perçus à la Gestion Environnementale}

\author{
JOHANNA FORSTER ${ }^{1,2 *}$, IAIN R. LAKE ${ }^{1}$, ANDREW R. WATKINSON ${ }^{1}$, and JENNIFER A. GILL ${ }^{3}$ \\ ${ }^{I}$ School of Environmental Sciences, University of East Anglia, Norwich NR4 7TJ, United Kingdom. \\ *johanna.forster@ncl.ac.uk. ${ }^{2}$ School of Marine Science and Technology, Ridley Building 2, Newcastle University, NE1 \\ 7RU, United Kingdom. ${ }^{3}$ School of Biological Sciences, University of East Anglia, Norwich NR4 7TJ, United Kingdom.
}

\section{EXTENDED ABSTRACT}

Islands are often considered to be a priority for conservation, because of their relatively high levels of biodiversity and their vulnerability to a range of natural and anthropogenic threats including invasive species, habitat change and increasingly climate change (Wong et al. 2005, Mimura et al. 2007). In a global analysis outlining conservation priority regions or 'biodiversity hotspots', nine out of 25 regions were comprised entirely or mainly of islands, and almost all tropical islands were represented by at least one hotspot region (Myers et al. 2000). Island ecosystems also provide important regulating, provisioning and cultural ecosystem goods and services for an estimated 500 million islanders (Wong et al. 2005, Fischlin et al. 2007). Threats to island ecosystems are therefore likely to have important socio-economic consequences for island economies and livelihoods through impacts on commercial and subsistence fisheries (Wong et al. 2005, Allison et al. 2009), tourism-dependent industries (Uvarra et al. 2005), and coastal protection (Fischlin et al. 2007).

The capacity of islands to conserve and manage biodiversity may, however, depend upon their governance structures (Douglas 2003). Many island states are affiliated to other countries through an 'overseas territory' status, which may provide them with access to resources and support mechanisms, but which may also influence the capacity for local-scale management of environmental issues (Oldfield and Sheppard 1997). The United Kingdom has links with 12 island Overseas Territories (UKOTs), most of which support biodiversity of high conservation concern (DEFRA 2009). The distant administration by the UK of its Overseas Territories (UKOTs) has led to a relatively removed approach to environmental management and biodiversity conservation issues (Oldfield and Sheppard 1997). The need for more effective environmental management and conservation in the UKOTs has recently gained political momentum, following the publication of a series of Parliamentary committee reports [e.g. see FAC 2008], as well as significant evidence from key non-governmental organisations (NGOs) [e.g. see RSPB 2007, Walling 2008).

In order to explore issues influencing environmental management in the UKOTs, this study investigates the perceptions of officials from the UK and Caribbean UKOTs of the environmental threats to marine ecosystems and biodiversity, and the constraints to environmental protection. This study focuses on the Caribbean UKOTs (Anguilla, Bermuda, British Virgin Islands, Cayman Islands, Montserrat, and the Turks and Caicos Islands), because they share features making them particularly at risk from marine and coastal biodiversity losses and are sensitive to a range of common environmental issues.

Individuals who were engaged specifically in environmental policy or governance in the UKOTs were interviewed. Respondents were either UK- or UKOT-based, and included representatives from each of the government departments with an environmental interest in the UKOTs and from conservation organisations engaged in environmental work in the UKOTs. The majority of interviews were undertaken during the International Union for Conservation of Nature (IUCN) conference on 'Climate Change and Biodiversity in the European Union Overseas Entities' in July 2008. Individuals who were not present at the conference were interviewed in London during October 2008. Interviews consisted of closed structured questions to generate quantitative data on the conservation status and threats to marine and coastal biodiversity in the Caribbean UKOTs. This was followed by a series of open-ended, semi-structured questions to provide qualitative responses on the resources available to manage environmental decline, and recommendations for the future management of the marine and coastal environment. All interviews were tape-recorded and transcribed verbatim.

Respondents were asked to rank the top three short-term (5 - 10 years) and long-term (10+ years) threats to the marine and coastal environments. Coastal development, pollution, and over-fishing were perceived as threats of most concern for the next decade, but climate change was perceived as by far the greatest future threat to the islands' marine ecosystems (Figure 1).

Respondents identified five major constraints to protecting marine and coastal ecosystems in the Caribbean, including insufficient personnel and financial support, a lack of long-term, sustainable projects for persistent environmental problems and inadequate environmental legislation (Table 1). 
Respondents highlight a multitude of threats affecting the coastal zone in the Caribbean UKOTs. The UKOTbased respondents considered current environmental risks from pollution, hurricanes, and coastal development to these islands' marine ecosystems to be greater short-term risks than those associated with climate change, but climate change was perceived to be the most significant long-term threat. By contrast, the UK-based respondents considered climate change to be the most important threat to these islands' marine ecosystems for short and long time-scales. The interviews revealed a variety of limitations to current environmental protection for islands, including insufficient



Short-term (5-10 yrs) threats

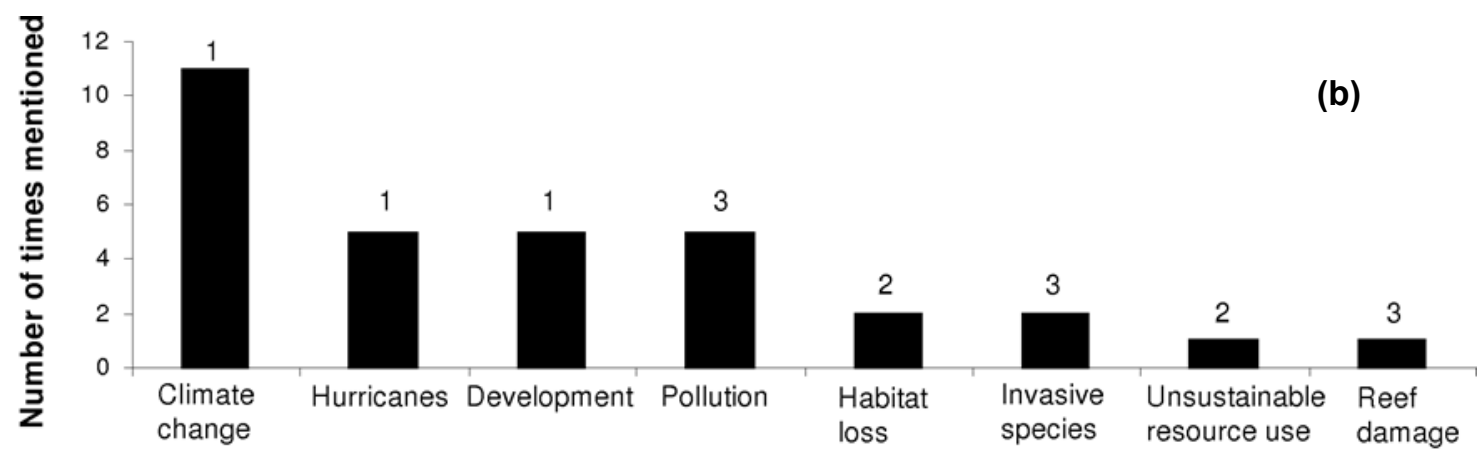

Long-term $(10+$ yrs) threats

Figure 1. Responses regarding perceptions of (a) short- and (b) long-term environmental threats to Caribbean UKOT marine and coastal ecosystems. Bar values depict the total number of times particular threats were mentioned by respondents. Numbers above bars denote the modal rank (or bimodal ranks) for each threat.

Table 1. Respondent responses regarding the major constraints to environmental protection in the Caribbean UKOTs. The number of respondents that mentioned a particular constraint is included, in addition to examples of respondent responses to contextualise each constraint category.

\begin{tabular}{|c|c|c|}
\hline Constraint category & $\begin{array}{l}\text { Number of } \\
\text { respondents }\end{array}$ & Selected respondent responses \\
\hline Insufficient financial support & 9 & $\begin{array}{l}\text { "There is a big shortfall between what is being provided and what is needed" } \\
\text { "Funding is very limited...I think all of us [UK and UKOT] could be doing more" }\end{array}$ \\
\hline Lack of environmental legislation & 7 & $\begin{array}{l}\text { "What you need is you need legislation in place" } \\
\text { "There's some [UKOTs] that don't have appropriate legislation to designate pro- } \\
\text { tected areas" }\end{array}$ \\
\hline $\begin{array}{l}\text { Reluctance to deal with climate } \\
\text { change }\end{array}$ & 6 & $\begin{array}{l}\text { "Some of the Territories are doing a lot...it tends to be the individuals seeing it } \\
\text { rather than the governments" } \\
\text { "The problem is that when a country has limited resources, environmental factors } \\
\text { do not become a priority" }\end{array}$ \\
\hline Human capacity & 4 & $\begin{array}{l}\text { "This is the big issue; the capacity in the islands is tiny. They are all under- } \\
\text { staffed... [the OTEP fund] is never spent fully" } \\
\text { "They've [UKOTs] got so few people they can't take on massive multi million pound } \\
\text { projects..." }\end{array}$ \\
\hline $\begin{array}{l}\text { Sustainable environmental pro- } \\
\text { grams }\end{array}$ & 3 & $\begin{array}{l}\text { "The problem is you need it [environmental work] to be sustainable, and the only } \\
\text { way it will be sustainable is if the [UKOT] government buys in..." } \\
\text { "We are satisfied with the small project funds, what's lacking is for longer projects" }\end{array}$ \\
\hline
\end{tabular}


financial support, out-dated environmental legislation, a reluctance by UKOT governments to address climate change, and a lack of long-term projects to manage climate change and other persistent environmental issues. These findings highlight the need for regional cooperation and capacity-building throughout the Caribbean and a more concerted approach to UKOT environmental management by the UK and UKOTs' governments.

\section{LITERATURE CITED}

Allison, E.H., A.L. Perry, M.C. Badjeck, W.N. Adger, K. Brown, D. Conway, et al. 2009. Vulnerability of national economies to the impacts of climate change on fisheries. Fish and Fisheries doi:10.1111/j.467-2979.008.00310x.

DEFRA. 2009. United Kingdom Overseas Territory biodiversity strategy. Department for Environment, Food and Rural Affairs. Westminster, United Kingdom.

Douglas, C.H. 2003. Sustainable socio-economic development and environmental policy for EU member states dependent Caribbean island territories for the $21^{\text {st }}$ century. Pages 245-277 in: Resources, Planning and Environmental Management in a Changing Caribbean. University of West Indies Press, Kingston, Jamaica.

FAC. Overseas Territories. 2008. House of Commons Foreign Affairs Committee, seventh report of session 2007-08 (HC 147-I).

Fischlin, A., G.F. Midgley, J. Price, R. Leemans, B. Gopal, C. Turley, et al. 2007. Ecosystems, their properties, goods and services. Pages 211-272 in: M.L. Parry, O.F. Canziani, J.P. Palutikof, P.J. van der Linden, and C.E. Hanson (eds.) Climate Change 2007: Impacts, Adaptation and Vulnerability. Cambridge University Press, Cambridge, United Kingdom.

Mimura, N., L. Nurse, R.F. McLean, J. Agard, L. Briguglio, P. Lefale, et al. 2007. Small islands. Pages 687-716 in: M.L. Parry, O.F. Canziani, J.P. Palutikof, P.J. van der Linden, C.E. Hanson (eds.) Climate Change 2007: Impacts, Adaptation and Vulnerability. Cambridge University Press, Cambridge, United Kingdom.

Myers, N., R.A. Mittermeier, C.G. Mittermeier, G.A.B. da Fonseca, and J. Kent. 2000. Biodiversity hotspots for conservation priorities. Nature 403:853-858.

Oldfield, S. and C. Sheppard. 1997. Conservation of biodiversity and research needs in the UK dependent territories. Journal of Applied Ecology 34:1111-1121.

RSPB. 2007. Costing Biodiversity Priorities in the UK Overseas Territories. Royal Society for the Protection of Birds, United Kingdom.

Uyarra, M.C., I.M. Côte', J.A. Gill, R.T.T. Tinch, D. Viner, and A.R Watkinson. 2005. Island preferences of tourists for environmental features: implications of climate change for tourism-dependent states. Environmental Conservation 32:11-19.

Walling, L.J. 2008. Climate change in the UK overseas territories: guidance for biodiversity conservation and management in a changing climate in the UK overseas territories. UK: Joint Nature Conservation Committee.

Wong, P.P., E. Marone, P. Lana, and M. Fortes. 2005. Island systems. Pages 663-680 in: R. Hassan, R. Scholes, and N. Ash (eds.) Millennium Ecosystem Assessment: Ecosystems and Human Wellbeing: Current State and Trends, Volume 1. Island press, Washington, D.C. USA. 